\title{
Large methane releases lead to strong aerosol forcing and reduced cloudiness
}

\author{
T. Kurtén ${ }^{1,2}$, L. Zhou ${ }^{1}$, R. Makkonen ${ }^{1}$, J. Merikanto ${ }^{1}$, P. Räisänen ${ }^{3}$, M. Boy ${ }^{1}$, N. Richards ${ }^{4}$, A. Rap ${ }^{4}$, S. Smolander $^{1}$, \\ A. Sogachev ${ }^{5}$, A. Guenther ${ }^{6}$, G. W. Mann ${ }^{4}$, K. Carslaw ${ }^{4}$, and M. Kulmala ${ }^{1}$ \\ ${ }^{1}$ Department of Physics, University of Helsinki, P.O. Box 64, 00014, Helsingin Yliopisto, Finland \\ ${ }^{2}$ Department of Chemistry, University of Copenhagen, Universitetsparken 5, 2100, København Ø, Denmark \\ ${ }^{3}$ Finnish Meteorological Institute, P.O. Box 503, 00101, Helsinki, Finland \\ ${ }^{4}$ Institute for Climate and Atmospheric Science, School of Earth and Environment, University of Leeds, Leeds, LS2 9JT, UK \\ ${ }^{5}$ Wind Energy Division, Ris $\varnothing$ National Laboratory for Sustainable Energy, Technical University of Denmark, Building 118, \\ P.O. Box 49, 4000, Roskilde, Denmark \\ ${ }^{6}$ Atmospheric Chemistry Division, NESL/NCAR, Boulder CO, USA
}

Received: 11 February 2011 - Published in Atmos. Chem. Phys. Discuss.: 16 March 2011

Revised: 5 July 2011 - Accepted: 13 July 2011 - Published: 18 July 2011

\begin{abstract}
The release of vast quantities of methane into the atmosphere as a result of clathrate destabilization is a potential mechanism for rapid amplification of global warming. Previous studies have calculated the enhanced warming based mainly on the radiative effect of the methane itself, with smaller contributions from the associated carbon dioxide or ozone increases. Here, we study the effect of strongly elevated methane $\left(\mathrm{CH}_{4}\right)$ levels on oxidant and aerosol particle concentrations using a combination of chemistry-transport and general circulation models. A 10fold increase in methane concentrations is predicted to significantly decrease hydroxyl radical $(\mathrm{OH})$ concentrations, while moderately increasing ozone $\left(\mathrm{O}_{3}\right)$. These changes lead to a $70 \%$ increase in the atmospheric lifetime of methane, and an $18 \%$ decrease in global mean cloud droplet number concentrations (CDNC). The CDNC change causes a radiative forcing that is comparable in magnitude to the longwave radiative forcing ("enhanced greenhouse effect") of the added methane. Together, the indirect $\mathrm{CH}_{4}-\mathrm{O}_{3}$ and $\mathrm{CH}_{4}-\mathrm{OH}-$ aerosol forcings could more than double the warming effect of large methane increases. Our findings may help explain the anomalously large temperature changes associated with historic methane releases.
\end{abstract}

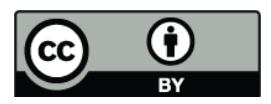

Correspondence to: $\mathrm{T}$. Kurtén (theo.kurten@helsinki.fi)

\section{Introduction}

Among the various worst-case scenarios for catastrophic climate change suggested over the past decades, the so-called clathrate-gun hypothesis (Kennett et al., 2000) is one of the most dramatic. In this scenario, a rise in temperatures leads to the destabilization and subsequent release of methane clathrates in the Arctic permafrost and seabed into the atmosphere, vastly amplifying the initial warming. This type of mechanism has been suggested as a possible reason for millennial-scale warming during the last ice age, as well as the Paleocene - Eocene Thermal Maximum (PETM; see e.g. Kennett et al., 2000), though the evidence so far is inconclusive (Clark et al., 2008; Sowers, 2006). One criticism of the hypothesis is that the amount of methane estimated to have been released during the PETM is not sufficient to explain the observed warming, at least if only the longwave radiative forcings of $\mathrm{CH}_{4}$ and its oxidation product $\mathrm{CO}_{2}$ are accounted for. For example Higgins and Schrag (2006) suggest that a large additional (non-methane) source of carbon is required to explain the PETM.

Estimates (see e.g. Clark et al., 2008) of the total size of the current methane clathrate reservoirs vary from some hundreds to several thousands of gigatons of carbon $(\mathrm{GtC})$. Even the low-end estimates are at least two orders of magnitude larger than current atmospheric methane content (about $5 \mathrm{Gt}$, or $4 \mathrm{GtC}$ ). If even a fraction of the clathrate reserves were to be released over anything less than millennial timescales, the atmospheric methane concentrations could thus potentially increase significantly.

Published by Copernicus Publications on behalf of the European Geosciences Union. 
Although the growth rate of methane concentrations in the atmosphere has decreased markedly in the past decade (Clark et al., 2008; Rigby et al., 2008), methane concentrations are predicted to rise significantly on a hundred-year timescale (Riahi et al., 2007). Moreover, recent observations (Hill et al., 2004; Shakova et al., 2010) of large methane emissions in Arctic areas have heated up the discussion on the "clathrate gun" hypothesis, at least in popular media. It is still uncertain whether these measurements represent a new source of atmospheric methane, and thus a potential feedback mechanism, or a previously unknown part of the natural cycle. In any case, even though a massive release of methane from clathrate reservoirs during this century is currently thought to be improbable, the potential implications of such a scenario warrant careful assessment of all potential effects, as well as consideration of possible $\mathrm{CH}_{4}$-related mitigation or geoengineering options (Boucher and Folberth, 2010).

In addition to the direct radiative effects of the methane itself, large methane emissions will have several indirect effects on the radiative balance. A large increase in the methane loading would increase the concentration of tropospheric ozone and stratospheric water vapor, while significantly decreasing the concentration of hydroxyl radicals $(\mathrm{OH})$ in the troposphere (Schmidt and Shindell, 2003; Clark et al., 2008; Shindell et al., 2009). The increased $\mathrm{O}_{3}$ and stratospheric water vapor concentrations lead (Schmidt and Shindell, 2003; Shindell et al., 2009) to an additional positive radiative forcing that is on the order of a few tens of percent of the direct longwave ("greenhouse-gas") forcing of methane itself. The decrease in $\mathrm{OH}$ concentrations reduces the oxidation rate, and thus increases the lifetime, of many pollutants and trace gases - including methane itself (Higgins and Schrag, 2006; Shindell et al., 2009). Furthermore, lower $\mathrm{OH}$ concentrations will reduce the formation rate of nucleating and condensing vapors (though this may partly be compensated by increased oxidation of some organic vapors by ozone), and lead to lower aerosol and cloud droplet number concentrations (CDNC). This will lower the average cloud albedo, decrease cloud lifetimes and cloudiness, and thus further warm the climate.

In a recent study (Shindell et al., 2009) the $\mathrm{CH}_{4}-\mathrm{OH}-$ aerosol - forcing was estimated to increase the global warming potential of present-day methane by approximately $40 \%$ (with large error bars) on a 100-yr time scale. However, since the different effects (direct $\mathrm{CH}_{4}, \mathrm{CH}_{4}-\mathrm{O}_{3}, \mathrm{CH}_{4}-\mathrm{OH}$-aerosol) all depend nonlinearly on the $\mathrm{CH}_{4}$ concentration, the relative magnitudes of the different forcings may be very different in a catastrophic clathrate release scenario. Schmidt and Shindell (2003) have assessed the $\mathrm{CH}_{4}-\mathrm{O}_{3}$ and stratospheric $\mathrm{H}_{2} \mathrm{O}$ - related forcings over a wide range of methane emission and concentration scenarios in a prehistoric scenario, but to our knowledge this has not been done for the potentially more significant $\mathrm{CH}_{4}-\mathrm{OH}$-aerosol forcing.

In this study, we have investigated the magnitude of the $\mathrm{CH}_{4}-\mathrm{OH}$-aerosol forcing, and compared it to the direct long- wave $\mathrm{CH}_{4}$ and $\mathrm{CH}_{4}-\mathrm{O}_{3}$ - forcings, for scenarios where the methane concentration increases by factors of 10 and 100 . We also investigated the effect of increasing $\mathrm{NO}_{\mathrm{x}}$ concentrations by a factor of 2 in a scenario where $\mathrm{CH}_{4}$ concentrations were increased by a factor of 10 . The $\mathrm{CH}_{4}-\mathrm{OH}$-aerosol forcing has been computed with two different global models: GLOMAP (Mann et al., 2010), which accounts only for the 1st indirect (cloud-albedo) aerosol effect, and ECHAM5HAM (Stier et al., 2005), which accounts for both the 1st and 2nd (cloud-lifetime) indirect effects. We also investigated the atmospheric chemistry changes associated with large methane increases using the 1-D chemistry - transport model SOSA (Boy et al., 2011).

\section{Computational details}

\subsection{Global models}

Oxidant fields were generated with the TOMCAT chemical transport model (Chipperfield, 2006), with $\mathrm{CH}_{4}$ concentrations fixed at different values (present-day, $10 \times$ present and $100 \times$ present). Emission estimates for year 2000 were used for all other chemical species. TOMCAT is a three-dimensional off-line chemical transport model (CTM). The model is forced using pre-defined large-scale transport and meteorology specified from 6-h European Centre for Medium-Range Weather Forecasts (ECMWF) analyses. TOMCAT includes a detailed tropospheric chemistry scheme (Arnold et al., 2005). In the applied version of TOMCAT, an additional isoprene chemistry scheme was added to the model. The model was run for the year 2005 with a $1-y r$ spin up, using T42 spectral resolution, which corresponds to a horizontal resolution of about $2.8^{\circ}$ by $2.8^{\circ}$, with 31 vertical levels up to $10 \mathrm{hPa}$.

We used a global aerosol model GLOMAP (Mann et al., 2010) and a general circulation model ECHAM5-HAM (Stier et al., 2005) to give independent estimates for how the changes in the oxidant predicted by the TOMCAT model change the aerosol forcing. TOMCAT oxidant fields were directly applied in the GLOMAP simulations, while the monthly mean oxidant fields of ECHAM5-HAM were scaled according to TOMCAT predictions. Both models used T42 spectral resolution and a similar aerosol microphysics set-up. Aerosol distributions are described using seven log-normal modes with one soluble nucleation mode, and both soluble and insoluble Aitken, accumulation and coarse modes, corresponding to the M7 setup (Vignati et al., 2004). Both models include emissions of primary elemental and organic carbon, sea salt, sulfate, and dust obtained from the AEROCOM emission inventory (Dentener et al., 2006). Secondary aerosol is produced by binary homogeneous nucleation of sulfuric acid and water and by an empirical activation nucleation mechanism (Sihto et al., 2006) in the boundary layer, where the nucleation rate of $1 \mathrm{~nm}$ particles is 
given by $J=2 \times 10^{-6} \mathrm{~s}^{-1}\left[\mathrm{H}_{2} \mathrm{SO}_{4}\right]$. The binary nucleation scheme of Vehkamäki et al. (2002) was used in ECHAM runs and the scheme of Kulmala et al. (1998) in GLOMAP runs. Both models also include a representation of secondary organic aerosol based on monoterpene emissions. ECHAM5HAM and GLOMAP apply prescribed monthly emissions of monoterpenes (Guenther et al., 1995) to estimate emissions of biogenic precursors for SOA. In ECHAM5-HAM, a fixed fraction of 0.15 of emitted BVOCs is assumed to form condensable SOA immediately after emission. The SOA production in ECHAM5-HAM is independent of oxidant fields. In GLOMAP, monoterpenes are oxidised to SOA in reactions with $\mathrm{O}_{3}, \mathrm{OH}$ and $\mathrm{NO}_{3}$ with fixed yields of 0.13 for each reaction. In GLOMAP, changes in oxidant fields affect the rate at which monoterpenes are transformed to SOA, but total SOA yields are nearly unaffected in different runs. Both models assume zero saturation vapor pressure for SOA products, so that SOA is partioned on the seven aerosol modes according to the relative condensation sinks of the modes.

The main difference between GLOMAP and ECHAM5HAM models is that ECHAM5-HAM generates its own winds and temperatures using climatological values for sea-ice concentration and sea surface temperatures, while GLOMAP uses a pre-defined large-scale transport and meteorology using ECMWF analyses. Since the ECHAM5-HAM model climate is not fixed, we ran the model for $5 \mathrm{yr}$ for a representative average of $\mathrm{CDNC}$ and radiative fluxes, while GLOMAP runs covered $1 \mathrm{yr}$ with 4 month spin-up with results based on the year 2005 climate. The two models also use different approaches for the calculations of cloud droplet number concentrations (CDNC) and cloud radiative forcings: in GLOMAP, boundary layer CDNC is post-processed from aerosol fields using the parameterization of Nenes and Seinfeld (2003), while in ECHAM5-HAM, aerosols are activated to cloud droplets according to the parameterization by Lin and Leaitch (1997), and reported CDNC values are analyzed at cloud-top height.

The indirect aerosol radiative forcing was evaluated as the change in the cloud radiative effect (defined as the difference between all-sky and clear-sky fluxes) at the top-ofatmosphere (TOA). For GLOMAP, only the first indirect aerosol effect was considered and it was evaluated using the offline Edwards and Slingo (1996) (E-S) radiative transfer model with cloud data from the International Satellite Cloud Climatology Project archive (Rossow and Schiffer, 1999) and a monthly averaged climatology based on the ECMWF reanalysis data (Rap et al., 2010). For ECHAM5-HAM, the simulated radiative fluxes are influenced by changes in CDNC as well as cloud fraction and condensate amounts; hence both the 1st and 2nd aerosol indirect effect are included. For aerosol-related forcings, the difference between TOA and tropopause values is likely negligible, so these values are comparable to the tropopause-level forcings calculated for $\mathrm{CH}_{4}$ and $\mathrm{O}_{3}$.
We also calculated the first indirect (cloud-albedo) forcing using ECHAM CDNC fields and the analysis methods of the GLOMAP and E-S models in order to assess the sensitivity of the results toward the details in the forcing calculations.

\subsection{1-D chemistry - transport models}

The 1-D chemistry - transport model SOSA (a model to simulate the concentrations of organic vapors and sulfuric acid) was used for detailed atmospheric chemistry simulations, with data from the field measurement station in Hyytiälä, Finland. The model builds upon an atmosphere boundary layer model SCADIS (Sogachev et al., 2002; Sogachev, 2009), which includes the vertical transport for moisture, heat, and for other compounds of interest. The chemistry was calculated with the Kinetic PreProcessor (KPP) with more than 2000 reactions generated by the Master Chemical Mechanism (MCM). Emissions of organic vapours (isoprene, monoterpene, etc.) were predicted by the model MEGAN. A detailed description of the model and initialization can be found in Boy et al. (2011). The initial concentration for methane was first set to mean concentration measured in Hyytiälä (1.8 ppm) to represent the current $\mathrm{CH}_{4}$ concentration scenario. By multiplying this initial value by 10 and 100 times we could then carry out the simulations under different $\mathrm{CH}_{4}$ concentration scenarios. The same procedure was applied to $\mathrm{NO}_{\mathrm{x}}$ to get different $\mathrm{NO}_{\mathrm{x}}$ concentration scenarios.

The effect of methane concentration increases on decreasing $\mathrm{OH}$ concentrations predicted by the SOSA model was very similar to that predicted by TOMCAT for the grid cell and column containing Hyytiälä, indicating that the lesser chemical detail of the global model is not a significant error source. On the other hand, the effect of increased $\mathrm{NO}_{\mathrm{x}}$ on $\mathrm{OH}$ concentrations was much greater in the SOSA simulations than in TOMCAT.

\section{3 $\mathrm{CH}_{4}$ and $\mathrm{O}_{3}$ radiative forcing calculations}

The radiative forcing due to increased methane concentrations was estimated in two phases. First, an estimate for the clear-sky radiative forcing was derived using the highly accurate (algorithmic accuracy approximately $0.5 \%$ ) Line-byLine-Radiative Transfer Model (LBLRTM; Clough and Iacono, 1995). Calculations for five McClatchey et al. (1971) standard atmospheres (tropical, midlatitude summer, midlatitude winter, subarctic summer and subarctic winter) yielded an estimate of $3.14 \mathrm{Wm}^{-2}\left(8.20 \mathrm{Wm}^{-2}\right)$ for the average clear-sky longwave radiative forcing at the tropopause level due to increasing the methane concentration by 10 (by 100). Impacts on shortwave radiation were not included. Second, the impact of clouds on methane radiative forcing was estimated roughly using the ECHAM5.4 radiation scheme (Mlawer et al., 1997; Cagnazzo et al., 2007). Off-line calculations for a global dataset extracted from a one-year 
ECHAM5.4 simulation suggested that clouds reduce the $\mathrm{CH}_{4}$ radiative forcing on average by $\sim 20 \%$. Therefore, we multiplied the clear-sky forcings from LBLRTM by 0.8 , which yields all-sky radiative forcings of $2.51 \mathrm{Wm}^{-2}$ and $6.56 \mathrm{Wm}^{-2}$ for 10 -fold and 100 -fold $\mathrm{CH}_{4}$ concentration, respectively. Note that the ECHAM5.4 scheme has not been designed to work well for such high $\mathrm{CH}_{4}$ concentrations. Therefore, we do not directly use the all-sky forcing for this scheme; it is only used to provide a rough estimate of how much clouds influence the forcing.

The net (longwave + shortwave) radiative forcing due to changed $\mathrm{O}_{3}$ concentration was estimated in off-line calculations with the ECHAM5.4 radiation scheme, using the aforementioned global dataset. The forcing was evaluated as the difference between calculations for (1) the scenarios with enhanced methane $\left(10 \times\right.$ and $\left.100 \times \mathrm{CH}_{4}\right)$ and (2) the reference scenario. In the reference scenario, $\mathrm{O}_{3}$ concentrations were kept at their present-day values. In the $10 \times$ and $100 \times \mathrm{CH}_{4}$ scenarios, the $\mathrm{O}_{3}$ concentration in each grid cell $(\mathrm{x}, \mathrm{y}, \mathrm{z})$ was multiplied by the annual mean fractional change in the $\mathrm{O}_{3}$ concentration predicted by the TOMCAT model for the location, while everything else was kept unchanged.

\section{$2.4 \mathrm{CH}_{4}$ lifetime estimation}

The lifetime of methane under different $\mathrm{OH}$ concentrations, $\tau_{\mathrm{CH}_{4}}([\mathrm{OH}])$, was computed as follows. First, the lifetime

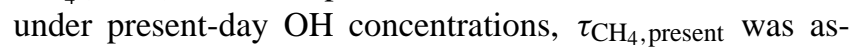
sumed to be $12 \mathrm{yr}$, as given in the IPCC 4 th assessment report (Solomon et al., 2007). Next, the total contribution of stratospheric and soil sinks given current $\mathrm{OH}$ levels $\left([\mathrm{OH}]_{\text {present }}\right)$ was assumed to be $12 \%$ of the total methane removal (Schmidt and Shindell, 2003; Solomon et al., 2007). The soil sink very likely does not depend on atmospheric $\mathrm{OH}$, $\mathrm{O}_{3}$ or $\mathrm{NO}_{\mathrm{x}}$ concentrations, and variations in the stratospheric sink due to tropospheric chemistry perturbations (and their effects in the stratosphere) are not likely to play a large role in the final lifetime of methane. Therefore, the rate constant associated with the combined non-tropospheric sinks (denoted $k_{\text {other }}$ ) was assumed to remain constant. The total removal rate, $R$, of methane then becomes:

$R=k_{\text {other }}\left[\mathrm{CH}_{4}\right]+k_{\mathrm{OH}}[\mathrm{OH}]\left[\mathrm{CH}_{4}\right]$

where $k_{\mathrm{OH}}$ is the average rate constant for removal by $\mathrm{OH}$, and we have assumed $k_{\text {other }}=(0.12 / 0.88) k_{\mathrm{OH}}[\mathrm{OH}]_{\text {present }}=$ $0.137 k_{\mathrm{OH}}[\mathrm{OH}]_{\text {present }}$. The lifetime is equal to the methane concentration divided by the removal rate: $\tau_{\mathrm{CH}_{4}}([\mathrm{OH}])=$ $1 /\left(k_{\mathrm{other}}+k_{\mathrm{OH}}[\mathrm{OH}]\right)$. Given these assumptions, the lifetime as a function of $\mathrm{OH}$ concentration can be expressed as:

$$
\begin{aligned}
\tau_{\mathrm{CH}_{4}}([\mathrm{OH}])= & \tau_{\mathrm{CH}_{4}, \text { present }} \times\left(k_{\mathrm{other}}+k_{\mathrm{OH}}[\mathrm{OH}]_{\text {present }}\right) \\
& /\left(k_{\mathrm{other}}+k_{\mathrm{OH}}[\mathrm{OH}]\right) \\
= & \tau_{\mathrm{CH}_{4}, \text { present }} \times 1.137 k_{\mathrm{OH}}[\mathrm{OH}]_{\text {present }} \\
& /\left(0.137 k_{\mathrm{OH}}[\mathrm{OH}]_{\text {present }}+k_{\mathrm{OH}}[\mathrm{OH}]\right)
\end{aligned}
$$

$$
\begin{aligned}
= & \tau_{\mathrm{CH}_{4}, \text { present }} \times 1.137 \\
& /\left(0.137+[\mathrm{OH}] /[\mathrm{OH}]_{\text {present }}\right)
\end{aligned}
$$

Thus, for example a halving of the atmospheric OH concentration would lead to a lifetime increase of a factor of about 1.8. The ratio $[\mathrm{OH}] /[\mathrm{OH}]_{\text {present }}$ was assumed to be roughly equal to the ratio of the average atmospheric concentrations of $\mathrm{OH}$ below $13 \mathrm{~km}$ in the simulation runs. (Using the total atmospheric average including stratospheric $\mathrm{OH}$ would tend to underestimate the changes, while using ground-level concentrations would tend to overestimate them.)

\section{Results and discussion}

The results of this study are summarized in Table 1 . The direct $\mathrm{CH}_{4}$ and $\mathrm{CH}_{4}-\mathrm{O}_{3}$ forcings are comparable to those published previously (Schmidt and Shindell, 2003; Shindell et al., 2009), with the $\mathrm{CH}_{4}-\mathrm{O}_{3}$ - forcing amounting to about $20 \%$ of the direct $\mathrm{CH}_{4}$ forcing in both scenarios. This is in agreement with the result of Shindell et al. (2009), who found that roughly one-fourth of the total present-day methane forcing (estimated to be $0.99 \mathrm{Wm}^{-2}$ ) is due to an increase in tropospheric ozone. Forcing from increased stratospheric $\mathrm{H}_{2} \mathrm{O}$ (due to $\mathrm{CH}_{4}$ oxidation in the stratosphere) was not assessed in this study, but is likely of the same order of magnitude - Schmidt and Shindell (2003) found the stratospheric $\mathrm{H}_{2} \mathrm{O}$ forcing to be between 23 and $29 \%$ of the total $\mathrm{CH}_{4}$ forcing for a range of paleoclimate scenarios.

Our modeling suggests that in a scenario where methane concentrations increase by a factor of 10 , the total indirect aerosol-related positive radiative forcing may be around $80 \%$ of the direct $\mathrm{CH}_{4}$ forcing. (Test calculations indicate that the direct aerosol forcing is negative, but below $0.1 \mathrm{Wm}^{-2}$ in absolute value.) The ECHAM5-HAM - simulations predict relatively large changes in global cloud cover and cloud water content, implying a strong secondary indirect aerosol effect. The difference between the GLOMAP and ECHAM5-HAM results, which occurs in spite of similar reductions in cloud droplet number concentration (CNDC) in the two models, suggests that cloud-albedo forcing accounts for somewhat less than half of the total aerosol forcing, with the (considerably more uncertain) cloud-lifetime forcing accounting for the rest. This ratio is similar to that obtained by Lohmann and Feichter (2005).

The relative ratios of the different forcings are similar for a 100-fold methane increase, though the absolute values of the CDNC and cloudiness changes and the corresponding forcings are naturally much larger. These results indicate that the total radiative forcing associated with large methane increases (including $\mathrm{CH}_{4}-\mathrm{O}_{3} \mathrm{CH}_{4}$,- $\mathrm{OH}$-aerosol and stratospheric $\mathrm{H}_{2} \mathrm{O}$ forcings) may be around twice as large as the direct longwave $\mathrm{CH}_{4}$ forcing alone. This may in part help 
ECHAM Net RF for $10 \times \mathrm{CH}_{4}$. Mean $=2.06 \mathrm{Wm}^{-2}$

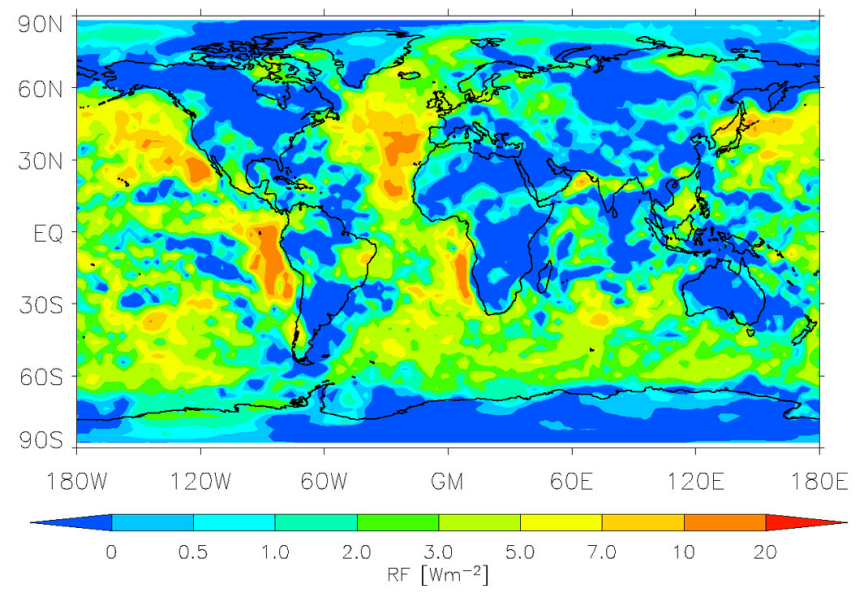

Fig. 1. Predicted aerosol radiative forcing (in $\mathrm{Wm}^{-2}$ ) (evaluated as a difference in cloud radiative forcing) associated with a $\mathrm{CH}_{4}$ concentration increased by a factor of 10, using ECHAM5-HAM.

ECHAM Net RF for $100 \times \mathrm{CH}_{4}$. Mean $=5.11 \mathrm{Wm}^{-2}$

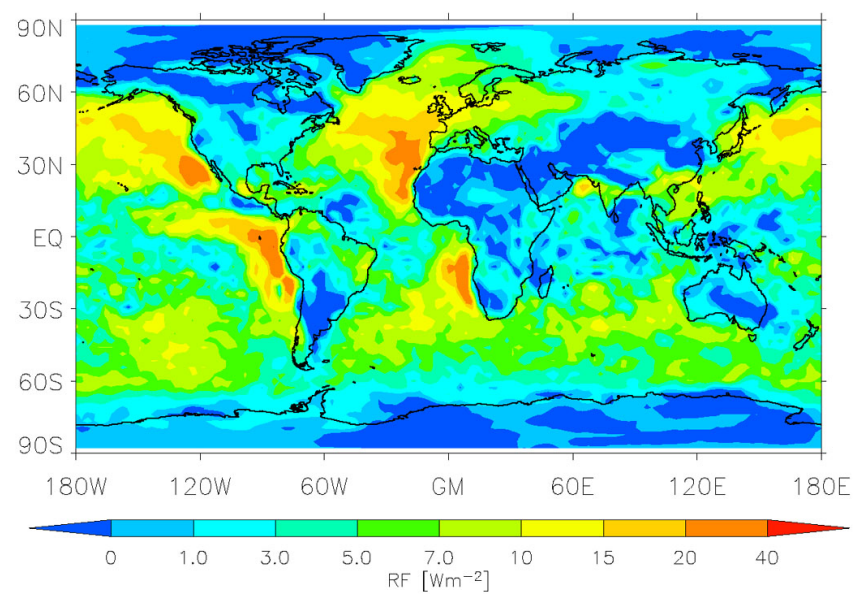

Fig. 2. Predicted total aerosol radiative forcing (in $\mathrm{Wm}^{-2}$ ) (evaluated as a difference in cloud radiative forcing) associated with a $\mathrm{CH}_{4}$ concentration increased by a factor of 100, using ECHAM5HAM.

resolve the discrepancy between estimated methane releases and warming during the PETM.

The aerosol-related forcings are caused mainly by perturbations to the sulfur cycle. In the high-methane scenarios, the oxidation of sulfur dioxide $\left(\mathrm{SO}_{2}\right)$ by $\mathrm{OH}$ into sulfuric acid $\left(\mathrm{H}_{2} \mathrm{SO}_{4}\right)$ in the gas phase becomes much less effective. This leads to smaller $\mathrm{H}_{2} \mathrm{SO}_{4}$ nucleation and condensation rates, and to $48 \%$ and $78 \%$ reductions in global Aitken mode sulfate masses in the 10-fold and 100-fold methane scenarios, respectively. However, in the high-methane scenarios a significantly larger fraction of $\mathrm{SO}_{2}$ is oxidized in the liquid phase (e.g. by $\mathrm{O}_{3}$ ), increasing the accumulation mode sulfate

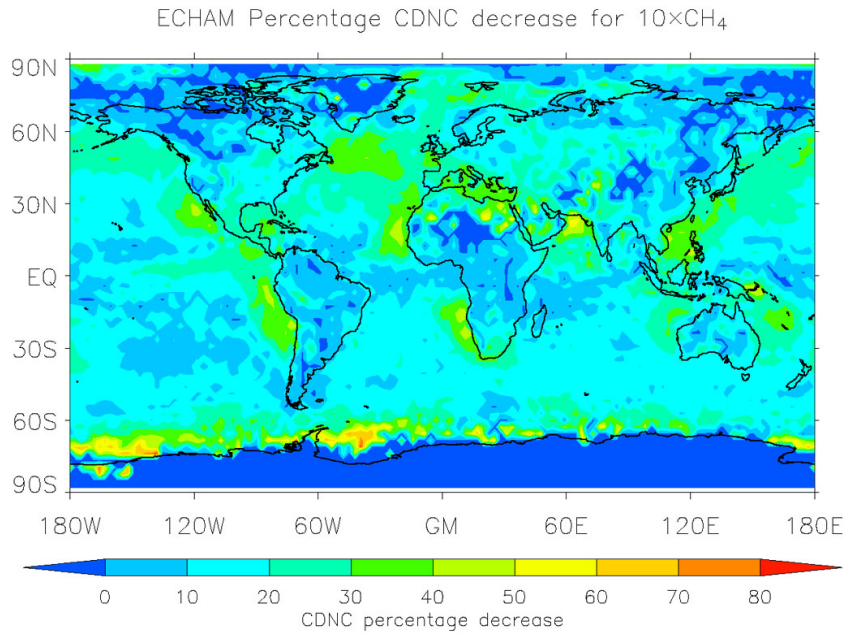

Fig. 3. Predicted percentage decrease in cloud droplet number concentration (CDNC) when the $\mathrm{CH}_{4}$ concentration is increased by a factor of 10, using ECHAM5-HAM.

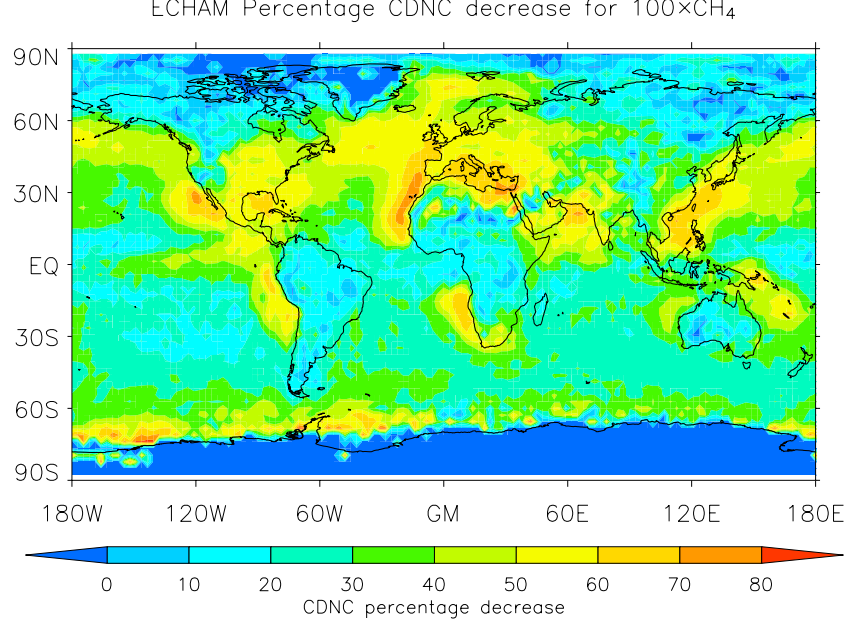

Fig. 4. Predicted percentage decrease in cloud droplet number concentration (CDNC) when the $\mathrm{CH}_{4}$ concentration is increased by a factor of 100, using ECHAM5-HAM.

masses by $9 \%$ and $15 \%$, respectively. Overall, the changes in Aitken mode aerosols dominate the changes in CDNC, and in the high-methane scenarios the aerosols that can act as cloud condensation nuclei are less numerous but larger. In contrast to $\mathrm{H}_{2} \mathrm{SO}_{4}$, the production rates of gaseous secondary organics remain nearly unaffected, while the fraction of organics oxidized by $\mathrm{O}_{3}$ increases relative to that oxidized by $\mathrm{OH}$ in the high-methane scenarios. It should be noted that the SOA formed by the different oxidants is assumed to be identical in the models. Also, while GLOMAP dynamically calculates the sources and sinks of $\mathrm{H}_{2} \mathrm{O}_{2}$, an important liquidphase oxidant of $\mathrm{SO}_{2}$, ECHAM5-HAM assumes fixed liquidphase oxidant concentrations. Since $\mathrm{H}_{2} \mathrm{O}_{2}$ concentrations 
Table 1. Average tropospheric $\mathrm{OH}$ concentration, estimated methane lifetime, global mean cloud droplet number concentration (CDNC), changes in the global-mean total and cloud cover and liquid water path, and various radiative forcing components (computed with respect to the present-day atmosphere) associated with three different methane concentrations. For CDNC and other cloud parameters, numbers shown in brackets are absolute values. $\mathrm{O}_{3}$ and $\mathrm{CH}_{4}$ forcings are computed at the tropopause, and aerosol-related forcings at the top of the atmosphere. LBLRTM = Line By Line Radiative Transfer Model. See the Computational Details - section for details.

\begin{tabular}{|c|c|c|c|}
\hline & Present day $\mathrm{CH}_{4}$ & $10 \times \mathrm{CH}_{4}$ & $100 \times \mathrm{CH}_{4}$ \\
\hline Tropospheric mass of $\mathrm{OH}$ & $152056 \mathrm{~kg}$ & $72834 \mathrm{~kg}$ & $25718 \mathrm{~kg}$ \\
\hline Average $\mathrm{OH}$ concentration below & $0.0605 \mathrm{ppt}_{\mathrm{V}}$ & $0.0319 \mathrm{ppt}_{\mathrm{V}}$ & $0.0130 \mathrm{ppt}_{\mathrm{V}}$ \\
\hline $13 \mathrm{~km}$ (TOMCAT) & & & \\
\hline Estimated methane lifetime* & $12 \mathrm{yr}$ & $20.5 \mathrm{yr}$ & $38.8 \mathrm{yr}$ \\
\hline CDNC (ECHAM) & $100 \%\left(215 \mathrm{~cm}^{-3}\right)$ & $82.1 \%\left(177 \mathrm{~cm}^{-3}\right)$ & $63.3 \%\left(137 \mathrm{~cm}^{-3}\right)$ \\
\hline CDNC (GLOMAP) & $100 \%\left(152 \mathrm{~cm}^{-3}\right)$ & $82.2 \%\left(125 \mathrm{~cm}^{-3}\right)$ & $66.2 \%\left(100 \mathrm{~cm}^{-3}\right)$ \\
\hline Cloud cover (ECHAM) & $100 \%(0.6509)$ & $99.3 \%(0.6465)$ & $98.4 \%(0.6408)$ \\
\hline Low cloud cover (ECHAM) & $100 \%(0.3604)$ & $98.6 \%(0.3552)$ & $96.3 \%(0.3469)$ \\
\hline $\begin{array}{l}\text { Cloud liquid water amount } \\
\text { (ECHAM) }\end{array}$ & $100 \%\left(70.27 \mathrm{~g} \mathrm{~m}^{-2}\right)$ & $87.8 \%\left(61.66 \mathrm{~g} \mathrm{~m}^{-2}\right)$ & $72.1 \%\left(50.65 \mathrm{~g} \mathrm{~m}^{-2}\right)$ \\
\hline $\mathrm{CH}_{4}$ forcing (LBLRTM) & - & $+2.51 \mathrm{Wm}^{-2}$ & $+6.56 \mathrm{Wm}^{-2}$ \\
\hline $\mathrm{O}_{3}$ forcing & - & $+0.76 \mathrm{Wm}^{-2}$ & $+1.13 \mathrm{Wm}^{-2}$ \\
\hline Total aerosol forcing (ECHAM) & - & $+2.32 \mathrm{Wm}^{-2}$ & $+5.54 \mathrm{Wm}^{-2}$ \\
\hline $\begin{array}{l}\text { Total indirect aerosol forcing } \\
\text { (ECHAM) }\end{array}$ & - & $+2.06 \mathrm{Wm}^{-2}$ & $+5.11 \mathrm{Wm}^{-2}$ \\
\hline $\begin{array}{l}1 \text { st indirect aerosol forcing } \\
\left(\text { GLOMAP }^{* *}\right)\end{array}$ & - & $+0.88 \mathrm{Wm}^{-2}$ & $+1.79 \mathrm{Wm}^{-2}$ \\
\hline $\begin{array}{l}\text { 1st indirect aerosol forcing } \\
\text { (ECHAM \& GLOMAP) }^{* * *}\end{array}$ & - & $+0.65 \mathrm{Wm}^{-2}$ & $+1.78 \mathrm{Wm}^{-2}$ \\
\hline
\end{tabular}

* Present-day lifetime taken from the IPCC 4th assessment report, other lifetimes scaled using the ratio of OH concentrations as described in the Computational Details - section.

** Includes only the cloud-albedo (1st indirect) aerosol effect. *** Cloud-albedo (1st indirect) aerosol effect computed with GLOMAP, using CDNC fields from ECHAM.

change significantly in the increased methane scenarios, the ECHAM-HAM5 results can not be considered to be realistic for liquid-phase oxidation.

Figures 1 and 2 show the regional distribution of the aerosol-related radiative forcing predicted by ECHAM5HAM following 10-fold and 100-fold increases in methane, respectively. Figures 3-4 show the corresponding CDNC changes, while Figs. 5 and 6 show the regional distribution of the cloud-albedo radiative forcings from the GLOMAP runs using the E-S radiation model. Figures 7 and 8 show the regional distributions of the cloud-albedo radiative forcings computed using ECHAM CDNC fields together with the GLOMAP and E-S analysis tools. The predicted effects of a large $\mathrm{CH}_{4}$ increase on aerosol forcings are largest over ocean areas, especially the eastern parts of the Atlantic and Pacific. This is due to three main reasons. First, the simulated fractional changes in CDNC are relatively large in these regions (Figs. 3-4), which implies relatively large changes in cloud optical depth and cloud albedo. Second, these regions feature abundant low cloudiness, which makes changes in cloud albedo particularly important for the radiation budget. Third, the lower albedo of the oceans compared to land areas leads to a greater total forcing for a similar change in cloud properties. The negative forcing observed in some equatorial re- gions in ECHAM5-HAM (but not in GLOMAP) is due to increase of cloud cover in these areas. While GLOMAP uses prescribed cloud fields of 2005, ECHAM5-HAM simulates changes in cloud cover between different experiments.

The computed forcings, especially the 2nd indirect aerosol effects, are associated with significant uncertainties. In addition to uncertainties in the actual cloud parameterizations, the aerosol microphysics models use a fairly simplistic nucleation parameterization, which assumes that the formation of new particles is mainly related to sulfuric acid concentrations. If organic ozonolysis products also participate in new-particle formation, this would tend to decrease the differences between present-day and high-methane scenarios, as methane emissions decrease $\mathrm{OH}$ but increase $\mathrm{O}_{3}$. This would weaken the total $\mathrm{CH}_{4}-\mathrm{OH}$-aerosol forcing compared to the values shown in Table 1 . Another potentially important mechanism not accounted for in this study is that the decreased clouds (and resulting increased solar radiation and surface temperature) associated with the increased methane might substantially increase the emissions of biogenic volatile organic compounds (VOC). This would lead to further decreases in $\mathrm{OH}$, but on the other hand would increase the yield of organic ozonolysis products. 
GLOMAP Net RF for $10 \times \mathrm{CH}_{4}$. Mean $=0.88 \mathrm{Wm}^{-2}$

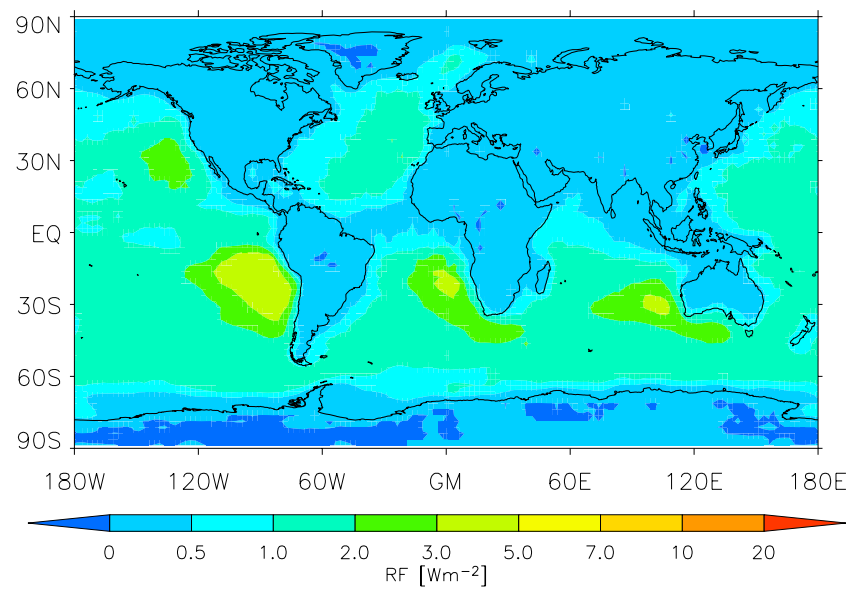

Fig. 5. Predicted cloud-albedo aerosol radiative forcing (in $\mathrm{Wm}^{-2}$ ) associated with a $\mathrm{CH}_{4}$ concentration increased by a factor of 10 , using GLOMAP and E-S.

GLOMAP Net RF for $100 \times \mathrm{CH}_{4}$. Mean $=1.79 \mathrm{Wm}^{-2}$

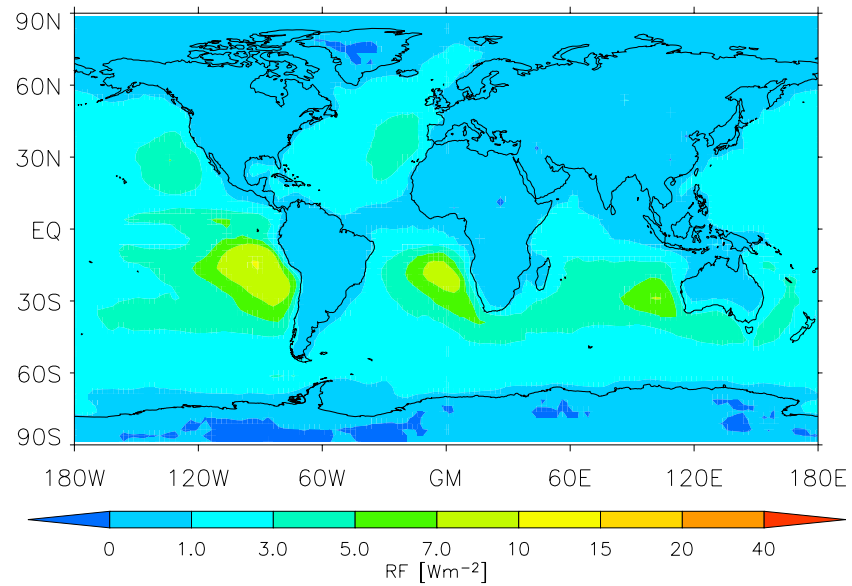

Fig. 6. Predicted cloud-albedo aerosol radiative forcing (in $\mathrm{Wm}^{-2}$ ) associated with a $\mathrm{CH}_{4}$ concentration increased by a factor of 100 , using GLOMAP and E-S.

We caution that the applicability of these results to explain prehistoric events (such as the PETM) is hampered by the difference between present industrial-age atmospheric chemistry and prehistoric conditions, as well as differences in the positions of the continents. For example, the overall ratio of new-particle formation to primary particle sources, and thus the effect of oxidant concentrations on cloud albedo, may have been very different during the PETM than today.

The prospect of methane-related feedback mechanisms has promoted a recent interest in the artificial removal of methane via geoengineering techniques (Boucher and Folberth, 2010). Even though the concentration of methane is much less than that of carbon dioxide, its much larger global
ECHAM \& GLOMAP Net RF for $10 \times \mathrm{CH}_{4}$. Mean $=0.65 \mathrm{Wm}^{-2}$

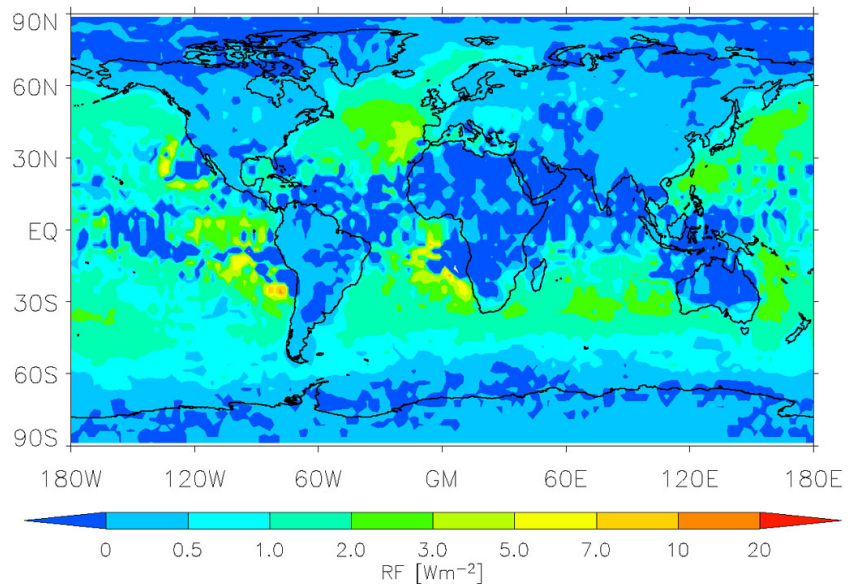

Fig. 7. Predicted cloud-albedo aerosol radiative forcing (in $\mathrm{Wm}^{-2}$ ) associated with a $\mathrm{CH}_{4}$ concentration increased by a factor of 10 , using GLOMAP and E-S with ECHAM CDNC fields.

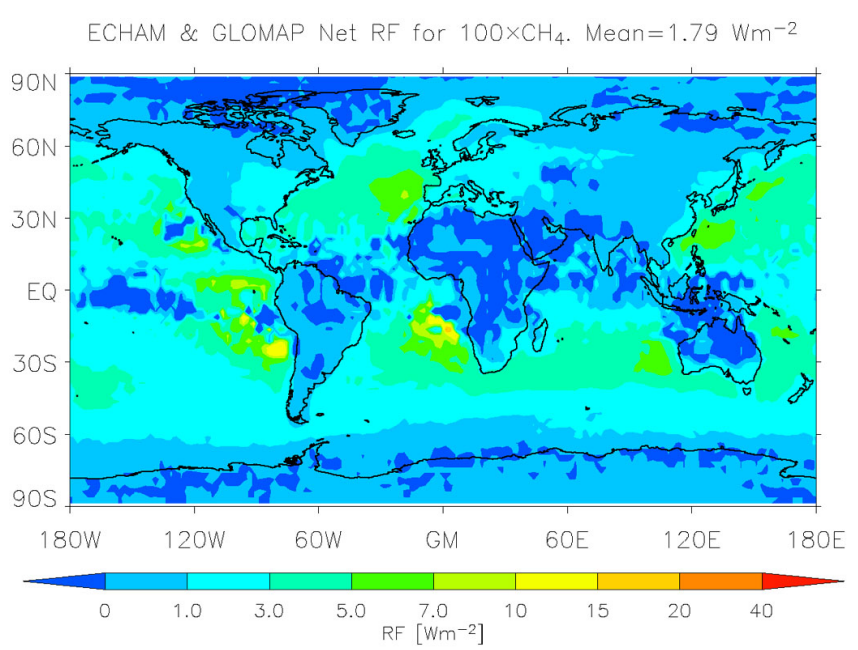

Fig. 8. Predicted cloud-albedo aerosol radiative forcing (in $\mathrm{Wm}^{-2}$ ) associated with a $\mathrm{CH}_{4}$ concentration increased by a factor of 100 , using GLOMAP and E-S with ECHAM CDNC fields.

warming potential (especially after the $\mathrm{O}_{3}$ - and aerosolrelated forcings are accounted for) makes methane removal an attractive option.

We have assessed the feasibility of perturbing tropospheric chemistry artificially in order to increase methane removal. As a proof-of-concept study, we have considered the catalytic effect of reactive nitrogen oxides $\left(\mathrm{NO}_{\mathrm{x}}\right)$ on methane oxidation. In most conditions, increasing the concentration of $\mathrm{NO}_{\mathrm{x}}$ leads to an increased $\mathrm{OH}$ concentration, and thus a more rapid $\mathrm{CH}_{4}$ oxidation, though at the expense of increased $\mathrm{O}_{3}$ levels. There probably exist potential $\mathrm{CH}_{4}$ removal catalysts that are both more effective and considerably less environmentally harmful than $\mathrm{NO}_{\mathrm{x}}$. (Side effects of $\mathrm{NO}_{\mathrm{x}}$ 
addition would include health and ecosystem damage due to air pollution and acidification, so $\mathrm{NO}_{\mathrm{x}}$ addition can thus not be recommended as a real-life mitigation measure.) However, we have conducted our simulations using $\mathrm{NO}_{\mathrm{x}}$ as a test case since the $\mathrm{NO}_{\mathrm{x}}-\mathrm{OH}-\mathrm{CH}_{4}$ chemistry is well known, and already included in atmospheric chemistry models.

Preliminary studies using the 1-D chemistry model SOSA (Boy et al., 2011) indicated that in a scenario with 10 times present methane concentration, e.g. a doubling of $\mathrm{NO}_{\mathrm{x}}$ levels would reduce the methane lifetime significantly (by almost $40 \%$ ). However, global chemistry model (TOMCAT) simulations for the same scenario indicated only a modest increase in tropospheric $\mathrm{OH}$ (from 0.0319 pptv to $0.0361 \mathrm{pptv}$ ), which corresponds to a reduction of the methane lifetime by only $9 \%$ (from 20.5 to $18.6 \mathrm{yr}$ ). The corresponding cloudalbedo related cooling associated with the $\mathrm{NO}_{\mathrm{x}}$ doubling computed by GLOMAP is only around $0.1 \mathrm{Wm}^{-2}$. The discrepancy between the 1-D model and the global model in the predicted $\mathrm{OH}-$ regeneration through increased $\mathrm{NO}_{\mathrm{x}}$ concentrations (about $50 \%$ ) is likely related to the more detailed chemistry included in SOSA. However, other factors like the different emission scenarios for organic vapors and the selected assumption of cloud-free conditions in the 1-D model could also be important factors.

\section{Conclusions}

Using a combination of atmospheric models, we show that the total radiative forcing associated with a large methane increase may be around twice as large as the direct greenhouse effect enhancement of the added methane. The main indirect forcing component is the decrease in cloud droplet number concentration, cloud fraction and condensate amount caused by a strong decrease in $\mathrm{OH}$ concentrations. We also investigated the effect of doubling atmospheric $\mathrm{NO}_{\mathrm{x}}$ levels in order to regenerate $\mathrm{OH}$, but found this hypothetical drastic geoengineering technique to be ineffective.

Acknowledgements. We thank the Academy of Finland for funding (project numbers 127210, 1127372 and 1118615). N. R. is funded by the NERC National Centre for Earth Observation (NCEO). We thank the CSC IT Centre for Scientific Computing in Espoo, Finland for computer resources.

Edited by: D. Shindell

\section{References}

Arnold, S. R., Chipperfield, M. P., and Blitz, M. A.: A threedimensional model study of the effect of new temperaturedependent quantum yields for acetone photolysis, J. Geophys. Res., 110, D22305, doi:10.1029/2005JD005998, 2005.

Boucher, O. and Folberth, G. A.: New Directions: Atmospheric methane removal as a way to mitigate climate change, Atmos. Environ., 44, 3343-3345, 2010.
Boy, M., Sogachev, A., Lauros, J., Zhou, L., Guenther, A., and Smolander, S.: SOSA - a new model to simulate the concentrations of organic vapours and sulphuric acid inside the ABL Part 1: Model description and initial evaluation, Atmos. Chem. Phys., 11, 43-1, doi:10.5194/acp-11-43-2011, 2011.

Cagnazzo, C., Manzini, E., Giorgetta, M. A., Forster, P. M. De F., and Morcrette, J. J.: Impact of an improved shortwave radiation scheme in the MAECHAM5 General Circulation Model, Atmos. Chem. Phys., 7, 2503-2515, doi:10.5194/acp-7-2503-2007, 2007.

Chipperfield, M.: New version of the TOMCAT/SLIMCAT offline chemical transport model: intercomparison of stratospheric tracer experiments, Q. J. Roy. Meteorol. Soc. 132, 1179-1203, 2006.

Clark, P. U., Weaver, A. J., Brook, E., Cook, E. R., Delworth, T. L., and Steffen, K: Abrupt Climate Change. A report by the U.S. Climate Change Science Program and the Subcommittee on Global Change Research, US Geological Survey, Reston, VA, 459 pp., 2008.

Clough, S. A. and Iacono, M. J.: Line-by-line calculations of atmospheric fluxes and cooling rates II: Application to carbon dioxide, ozone, methane, nitrous oxide, and the halocarbons, J. Geophys. Res., 100, 16519-16535, 1995.

Dentener, F., Kinne, S., Bond, T., Boucher, O., Cofala, J., Generoso, S., Ginoux, P., Gong, S., Hoelzemann, J. J., Ito, A., Marelli, L., Penner, J. E., Putaud, J.-P., Textor, C., Schulz, M., van der Werf, G. R., and Wilson, J.: Emissions of primary aerosol and precursor gases in the years 2000 and 1750 prescribed data-sets for AeroCom, Atmos. Chem. Phys., 6, 4321-4344, doi:10.5194/acp6-4321-2006, 2006.

Edwards, J. M. and Slingo, A.: Studies with a flexible new radiation code I: choosing a configuration for a large-scale model, Q. J. Roy. Meteorol. Soc., 122, 689-719, 1996.

Guenther, A., Hewitt, N. C., Erickson, D., Fall, R., Geron, C., Graedel, T., Harley, P., Klinger, L., Lerdau, M, Mckay, W. A., Pierce, T., Scholes, B., Steinbrecher, R., Tallamraju, R., Taylor, J., and Zimmerman, P.: A global model of natural volatile organic compound emissions, J. Geophys. Res., 100(D5), 88738892, doi:10.1029/94JD02950, 1995.

Higgins, J. A. and Schrag, D. P.: Beyond methane: Towards a theory for the Paleocene-Eocene Thermal Maximum, Earth Planet. Sci. Lett., 245, 523-537, 2006.

Hill, T. M., Kennett, J. P., and Spero, H. J.: High-resolution records of methane hydrate dissociation: ODP Site 893, Santa Barbara Basin, Earth Planet. Sci. Lett., 223, 127-140, 2004.

Kennett, J. P., Cannariato K. G., Hendy, I. L., and Behl, R. J.: Carbon Isotopic Evidence for Methane Hydrate Instability During Quaternary Interstadials, Science, 288, 128-133, 2000.

Kulmala, M., Laaksonen, A., and Pirjola, L..: Parameterizations for sulfuric acid/water nucleation rates, J. Geophys. Res.-Atmos., 103(D7), 8301-8307, 1998.

Lin, H. and Leaitch, W. R.: Development of an in-cloud aerosol activation parameterization for climate modelling, Proc. WMO Workshop on Measurement of Cloud Properties for Forecasts of Weather, Air Quality and Climate, Geneva, Switzerland, World Meteorology Organization, 328-355, 1997.

Lohmann, U. and Feichter, J.: Global indirect aerosol effects: a review, Atmos. Chem. Phys., 5, 715-737, doi:10.5194/acp-5-7152005, 2005. 
Mann, G. W., Carslaw, K. S., Spracklen, D. V., Ridley, D. A., Manktelow, P. T., Chipperfield, M. P., Pickering, S. J., and Johnson, C. E.: Description and evaluation of GLOMAP-mode: a modal global aerosol microphysics model for the UKCA composition-climate model, Geosci. Model Dev., 3, 519-551, doi:10.5194/gmd-3-519-2010, 2010.

McClatchey, R. A., Fenn, R. W., Selby, J. E. A, Volz, F. E, and Garing, J. S.: Optical properties of the atmosphere, Report AFCRL-71-0279, Available from Air Force Geophysics Laboratory, Hanscom Air Force base, MA 01731, USA, 1971.

Mlawer, E. J., Taubman, S. J., Brown, P. D., Iacono, M. J., and Clough, S. A.: Radiative transfer for inhomogeneous atmospheres. RRTM, a validated correlated-k model for the longwave, J. Geophys. Res., 102, 16663-16682, 1997.

Nenes, A. and Seinfeld, J.H.: Parameterization of cloud droplet formation in global climate models., J. Geophys. Res., 108, 4415, doi:10.1029/2002JD002911, 2003.

Rap, A., Forster, P. M., Jones, A., Boucher, O., Haywood, J. M., Bellouin, N., and De Leon, R. R.: Parameterization of contrails in the UK Met Office Climate Model., J. Geophys. Res., 115, D10205, doi:10.1029/2009JD012443, 2010.

Riahi, K., Gruebler, A., and Nakicenovic, N.: Scenarios of long-term socio-economic and environmental development under climate stabilization, Technological Forecasting and Social Change, 74(7), 887-935, 2007.

Rigby, M., Prinn, R. G., Fraser, P. J., Simmonds, P. G., Langenfelds, R. L., Huang, J., Cunnold, D. M., Steele, L. P., Krummel, P. B., Weiss, R. F., O'Doherty, S., Salameh, P. K., Wang, H. J., Harth, C. M., Mühle, J., and Porter, L. W.: Renewed growth of atmospheric methane, Geophys. Res. Lett., 35, L22805, doi:10.1029/2008GL036037, 2008.

Rossow, W. B. and Schiffer, R. A.: Advances in understanding clouds from ISCCP, B. Am. Meteorol. Soc., 80, 2261-2288, 1999.

Schmidt, G. and Shindell, D. T.: Atmospheric composition, radiative forcing, and climate change as a consequence of a massive methane release from gas hydrates, Paleoceanography, 18, 1004, doi:10.1029/2002PA000757, 2003.

Shakhova, N., Semiletov, I., Salyuk, A., Yusupov, V., Kosmach, D., and Gustafsson, Ö.: Extensive Methane Venting to the Atmosphere from Sediments of the East Siberian Arctic Shelf, Science, 327, 1246-1250, 2010.
Shindell, D. T., Faluvegi, G., Koch, D. M., Schmidt, G. A., Unger, N., and Bauer, S. E.: Improved Attribution of Climate Forcing to Emissions, Science, 326, 716-718, 2009.

Sihto, S.-L., Kulmala, M., Kerminen, V.-M., Dal Maso, M., Petäjä, T., Riipinen, I., Korhonen, H., Arnold, F., Janson, R., Boy, M., Laaksonen, A., and Lehtinen, K. E. J.: Atmospheric sulphuric acid and aerosol formation: implications from atmospheric measurements for nucleation and early growth mechanisms, Atmos. Chem. Phys., 6, 4079-4091, doi:10.5194/acp-6-4079-2006, 2006.

Sogachev, A.: A note on two-equation closure modelling of canopy flow, Bound. Lay. Meteorol., 130, 423-435, 2009.

Sogachev, A., Menzhulin, G., Heimann, M., and Lloyd, J.: A simple three dimensional canopy - planetary boundary layer simulation model for scalar concentrations and fluxes, Tellus, 54B, 784819, 2002.

Solomon, S., Qin, D., Manning, M., Marquis, M., Averyt, K., Tignor, M. M. B., Miller Jr., H. L., and Chen, Z.(Eds.): Contribution of Working Group I to the Fourth Assessment Report of the Intergovernmental Panel on Climate Change, 2007, Cambridge University Press, Cambridge, United Kingdom and New York, NY, USA, 2007.

Sowers, T.: Late Quaternary Atmospheric $\mathrm{CH}_{4}$ Isotope Record Suggests Marine Clathrates Are Stable, Science, 311, 838-840, 2006.

Stier, P., Feichter, J., Kinne, S., Kloster, S., Vignati, E., Wilson, J., Ganzeveld, L., Tegen, I., Werner, M., Balkanski, Y., Schulz, M., Boucher, O., Minikin, A., and Petzold, A.: The aerosolclimate model ECHAM5-HAM, Atmos. Chem. Phys., 5, 11251156, doi:10.5194/acp-5-1125-2005, 2005.

Vehkamäki, H., Kulmala, M., Napari, I., Lehtinen, K. E. J., Timmreck, C., Noppel, M., and Laaksonen, A.: An improved parameterization for sulfuric acid/water nucleation rates for tropospheric and stratospheric conditions, J. Geophys. Res. 107(D22), doi:10.1029/2002JD002184, 2002.

Vignati, E., Wilson, J., and Stier, P.: M7: An efficient size-resolved aerosol microphysics module for large-scale aerosol transport models, J. Geophys. Res., 109, D22202, doi:10.1029/2003JD004485, 2004. 